\title{
The Humboldt Fellowships for Eastern Europe During the Cold War: Politics and Numbers'
}

\author{
Irina NASTASĂ-MATEI
}

\begin{abstract}
The Alexander von Humboldt Foundation was re-established in the Federal Republic of Germany in 1953, with the aim of demonstrating that Germany continued to be a great cultural power and of marking its place on the international arena. It awarded very prestigious fellowships to researchers from abroad, based on the criteria of academic excellence and lack of quotas. Even if sporadically at the beginning, the Foundation's relationship with the countries of Eastern Europe started to develop in the late 1960s, despite the opposite political systems of the two blocs. This happened in the context of the FRG's East-centered foreign policy (Ostpolitik), and was also due to the opening of socialist countries to the West. The relationship, however, was marked in many cases by tensions, as political interests, as opposed to the cultural or academic dimension, prevailed. The article tackles the situation of the Humboldt fellows from Eastern Europe during the Cold War, focusing, from a comparative perspective, on the quantitative aspect, as well as on the political dynamics which determined their presence in West Germany.
\end{abstract}

Keywords: West Germany, Soviet bloc, Cold War; academic relations; Humboldt fellowships.

The Alexander von Humboldt Foundation has been an important vector of academic collaboration, as well as of the configuration and coordination of the cultural policy and cultural diplomacy of the Federal Republic of Germany (FRG). Consequently, analysing the dynamics of granting fellowships and the Foundation's collaboration with various countries of the world is a precise indicator of the FRG's interest in one region or another, and of the way West Germany's relations with those countries functioned during the Cold War, despite the Foundation's policy of not establishing quotas based on regional - or any other - criteria.

This article aims to analyze the academic relations between West Germany and the countries of the Eastern bloc, using as the main variable the granting of Humboldt fellowships to scholars coming from these countries. Although based, theoretically, only on the quality of the applications, the granting of these fellowships proved to be dependent on the political relations of the FRG

1 This work was supported by a grant of the Ministry of Research and Innovation, CNCS - UEFISCDI, project number PN-III-P1-1.1-PD-2016-0610, within PNCDI III 
with the states from where the applications were received, since the access to information and a greater number of applications meant automatically a greater number of recipients. In addition, the political issues involved in the decisionmaking process, and especially in the implementation of the West German offer, were decisive.

The analysis of the relationship between the FRG and the countries of the Soviet bloc reveals a rather coherent policy promoted by West Germany towards the socialist countries. One can notice certain specific features of this collaboration, which proved to be common in the relationship with all these countries and which were mainly due to the political regimes in power at the time - communist, autoritarian regimes, based on planning and control - and to the loyalty level towards USSR or GDR, which varied. However, the comparative analysis highlights also the differences in the academic exchange dynamics, due to the same factors as the similarities: a various and fluctuating level of ideological control in each socialist country during the Cold War, and a fluctuating dynamic of relations within the Soviet bloc, especially concerning the other communist countries' relations with the German Democratic Republic and with the USSR.

The topic of the academic exchange between the FRG and the countries of the Eastern bloc should be placed in the context of relatively recent scholarly developments in Cold War studies. While, traditionally, the literature regarding the Cold War focused on political, military and economic developments, which favored the perspective of conflict and rivalry between the two sides, new approaches increasingly focus on instances of collaboration and exchange. These perspectives go beyond the long-established paradigm of dichotomy and antagonism between Good vs. Evil, Capitalism vs. Communism, Liberal vs. Authoritarian regimes. These analyses show that the Iron Curtain was, in fact, a "semipermeable membrane" ${ }^{2}$ or a "nylon curtain", and that cooperation and joint efforts between the East and West were possible, and did indeed occur. This happened, for example, in those cases when both blocs were fighting against

2 Michael David-Fox, „The Iron Curtain as Semi-Permeable Membrane: The Origins and Demise of the Stalinist Superiority Complex", in Patryk Babiracki and Kenyon Zimmer, eds., Cold War Crossings: International Travel and Exchange Across the Soviet Bloc, 1940s-1960s (College Station: Texas A\&M University Press, 2014), 14-40.

3 György Péteri, Nylon Curtain: Transnational and Transsystemic Tendencies in the Cultural Life of State-Socialist Russia and East-Central Europe (Trondheim: Program on East European Cultures and Societies, 2006). See also Simo Mikkonen, Pia Koivunen, eds., Beyond the Divide: Entangled Histories of Cold War Europe (New York: Berghahn Books, 2015); Sari Autio-Sarasmo and Brendan Humphreys, eds., Winter Kept Us Warm: Cold War Interactions Reconsidered. (Aleksanteri Cold War Series). (Helsinki: University of Helsinki Press, 2010). 
common threats, such as epidemics, or when the exchange of medical knowledge and the shared efforts towards producing a vaccine ignored the existing political and ideological barriers ${ }^{4}$. The pursuit of leisure was another instance in which the borders were more easily crossed. Tourism across the Iron Curtain was also a part of the "cultural diplomacy" or "soft power"s projected by the states involved ${ }^{6}$. In this respect, particularly notable are some relatively recent works on the cultural diplomacy of the Soviet Union ${ }^{7}$, the research discussing the United States' soft power strategies in Eastern Europe and the USSR ${ }^{8}$, as well as certain recent publications in the field of scienctific and academic diplomacy, which focus on the period of the Cold War' 9

Academic and student migration are complex phenomena which cannot be completely covered or explained by the concepts of "cultural diplomacy" or "soft power." However, they can be viewed as exemplary models of these notions. Significant and innovative literature has been published on the patterns of cultural and academic collaboration between East and West ${ }^{10}$, as well as

4 See Dora Vargha, Polio Across the Iron Curtain: Hungary's Cold War with an Epidemic (Cambridge: Cambridge University Press, 2018).

5 A concept introduced by Joseph Nye for describing the strategy of exercising influence or ascendancy by using the strategy of appeal and attraction instead of force or coercion ("hard power”). See Joseph S. Nye, “Soft Power”, in Foreign Policy 80, no. 3 (1990): 153-171.

6 Sune Bechmann Pedersen, Christian Noack, eds., Tourism and Travel during the Cold War. Negotiating Tourist Experiences Across the Iron Curtain (London: Routledge, 2020).

7 Michael David-Fox, Crossing Borders: Modernity, Ideology, and Culture in Soviet Russia (Pittsburgh: University of Pittsburgh Press, 2015); Michael David-Fox, Showcasing the Great Experiment: Cultural Diplomacy and Western Visitors to the Soviet Union, 1921-1941 (New York: Oxford University Press, 2012). See also Frederick Barghoorn, The Soviet Cultural Offensive: The Role of Cultural Diplomacy in Soviet Foreign Policy (Westport: Greenwood Press, 1976); Nigel Gould-Davies, “The Logic of Soviet Cultural Diplomacy”, in Diplomatic History 27, no. 2 (2003): 193-214.

8 Walter L. Hixson, Parting the Curtain: Propaganda, Culture, and the Cold War, 1945-1961 (New York: St. Martin's Press, 1997).

9 Pierre-Bruno Ruffini, Science and Diplomacy. A New Dimension of International Relations (New York: Springer, 2017); Alison Kraft, Carola Sachse, Science, (Anti-)Communism and Diplomacy. The Pugwash Conferences on Science and World Affairs in the Early Cold War (Leiden: Brill, 2019); Glenn E. Schweitzer, Scientists, Engineers, and Two-Track Diplomacy: A Half-Century of U.S.-Russian Interacademy Cooperation (Washington, DC: National Academies Press, 2004).

${ }^{10}$ Denis Kallen, "New Perspectives on Academic Exchange Between Eastern and Western Europe", in Higher Education in Europe 15, no. 1 (1990): 12-22; Allen H. Kassof, "Scholarly Exchanges and the Collapse of Communism”, in Soviet and Post-Soviet Review 22, no. 3 (1995): 263-274; Liping Bu, "Educational Exchange and Cultural Diplomacy in the Cold War", in Journal of American Studies 33, no. 3, Part 1: Women in America (December 1999): 393-415; Jeroen van Dongen, ed., Cold War Science and the Transatlantic Circulation of Knowledge (Leiden: Brill, 2015). 
concerning the relevant case studies ${ }^{11}$. However, the topic of the 'soft power' role of the academic exchanges between Soviet Russia and the United States has held pride of place ${ }^{12}$, while equaly interesting case studies, which did not involve these two superpowers as main actors, are still underresearched. This is also the case of the fellowship system established by the Federal Republic of Germany during the Cold War, a subject which still needs to be researched and analyzed in depth. The literature on the relations and academic collaboration between West Germany and various East European countries is also scarce - at least if one takes into account publications printed in English or German. This state of the art makes it difficut to establish the proper context in which this variety of academic migration patterns unfolded.

This article deals, in particular, with the granting of fellowships by the Alexander-von-Humboldt Foundation to scholars from Yugoslavia, Poland, Hungary, Bulgaria, Romania, Czechoslovakia and the USSR.

\section{The relations between}

\section{the FRG and the countries of the Eastern bloc}

The Federal Republic of Germany was established on May 23, 1949, and consisted of three - out of the four - military occupation zones: the French, the British and the US-American. On October 7, 1949, the German Democratic Republic was founded, as a socialist state, in the former Soviet zone. Both German states claimed to be the „true” Germany, refusing for a long period to recognize each other and, implicitly, to maintain relations of any kind.

In the first years after the establishment of West Germany, its relations with the countries of Eastern Europe were very limited, for obvious reasons. The FRG was primarly concerned with its reconstruction and with the development of a strong, sustainable political and economic system. Consequently, its most important partners at this time could only be other Western states, which were economically strong and with which the FRG shared the same economic values and the same political system. Therefore, the 1950s were marked by the strengthening of West Germany's relationship with countries such as Great Britain and the United States, which invested in the reorganiza-

${ }^{11}$ See, for example: Ludovic Tournès, Giles Scott-Smith, eds., Global Exchanges: Scholarships and Transnational Circulations in the Modern World (Oxford \& New York: Berghahn Books, 2017).

${ }^{12}$ See: Yale Richmond, Cultural Exchange and the Cold War: Raising the Iron Curtain (University Park: Pennsylvania State University Press, 2003); Campbell F. Scribner, "American Teenagers, Educational Exchange, and Cold War Politics”, in History of Education Quarterly 57, no. 4 (2017): 542-569. 
tion and reconstruction of the FRG, and by the laying of the foundations of the European community ${ }^{13}$.

On the other hand, the Eastern European countries, being under the influence of the USSR, with a different political regime and ideology than the West, maintained relations mainly with the other socialist states. Moreover, after having signed the Warsaw Pact in 1955, the Eastern European countries had very close relations with the German Democratic Republic. This meant that, of all the Western countries, with which some communist states still had various economic and cultural collaboration projects, the FRG was the only country with which any cooperation was tabooed, since it was viewed as a betrayal of the GDR, a sabotage of its status as the only German state recognized by the entire Soviet bloc.

The 1950s and early 1960s were a time when the Cold War was displayed in various ways, being close to becoming very „hot” on several occasions (e.g., during the Cuban missile crisis in 1962). FRG's relations with the socialist countries during this period were marked by mutual distrust and ideological conflict. While the Bonn authorities expressed concern about the social and political developments in the Soviet bloc (political purges, censorship, nationalization and collectivization, etc.), being especially worried about the human rights violations in these countries, within the opposite camp West Germany was accused of pursuing an „imperialist” policy.

The 1960s, however, brought a gradual rapprochement between the FRG and the countries of the Soviet bloc. For the West German politicians, the stakes were clear: by attempting to make their presence felt and play an economic, political and cultural role in these countries, they were trying to present the FRG as a viable German partner, more convenient than the GDR ${ }^{14}$. The strategy of implementing a soft-power policy in Eastern Europe, which was aimed at turning West Germany into an important political actor in this region, was followed by a clear, well-designed policy of political rapprochement with the socialist countries in the East, including the GDR: the so-called "Ostpolitik"15.

${ }^{13}$ See: Tony Judt, Postwar: A History of Europe since 1945 (New York: The Penguin Press, 2005); Detlef Junker, ed., The United States and Germany in the Era of the Cold War, 1945-1990. A Handbook. Volume 1: 1945-1968 (Cambridge: Cambridge University Press, 2004).

${ }^{14}$ See: William Glenn Gray, Germany's Cold War: The Global Campaign to Isolate East Germany, 1949-1969 (Chapell Hill, NC: The University of North Carolina Press, 2003).

${ }^{15}$ West German foreign policy promoted by Willy Brandt, Foreign Affairs Minister between 1966 and 1969 and Chancellor between 1969 and 1974. It marked the start of the FRG-GDR collaboration and the beginning of the FRG's relations with Soviet bloc states. See: Carole Fink, Bernd Schaefer, eds., Ostpolitik, 1969-1974: European and Global Responses (Cambridge: Cambridge University Press, 2008). 
More or less willingly or reluctantly, the socialist countries had their own reasons for developing relations with the FRG, including economic, financial interests; the intention to import knowledge and technology from this highly developed state; the existence of an old tradition of collaboration with certain institutions that were now located in West Germany; the wish to show some autonomy with respect to the USSR in their foreign policy. A consistent collaboration between West Germany and the countries of the Eastern bloc was initiated in the mid-1960s ${ }^{16}$, in a context marked by ideological and political relaxation in the communist countries, a context in which even the USSR explored a closer relationship with the FRG and with other West European countries, including the USA ${ }^{17}$.

The conflicting political systems did not allow, however, for a consistent development of these relations, which soon showed their limits. Initially, the FRG considered an economically centered collaboration, through opening commercial agencies in the countries of the Soviet bloc ${ }^{18}$. Diplomatic relations with the socialist states were then established during the interval 1967-1973 - at the beginning of the above-mentioned period of "Ostpolitik" - which represented a great victory for West German foreign policy (especially in relation to the GDR), and which ensured, in the long run, up to the end of the Cold War, the continued existence of relations with these countries, despite the alternation of periods of relaxation with periods of strict control and ideological conflict.

\section{The academic relations}

\section{between the FRG and the countries of the Eastern bloc}

The cultural and academic relations between the FRG and the socialist countries were established in the context of a certain distancing of the Eastern European states from Soviet hegemony, and of their willingness to resume relations with Western Europe at a formal, political and diplomatic level.

The first socialist country with which the FRG began to cooperate was Yugoslavia. Josip Tito had allowed Yugoslav citizens to travel freely to West Germany since the 1950s, with many of them employed there as migrant workers (Gastarbeiter). This also led to a cultural rapprochement in the sphere of ideas and val-

${ }^{16}$ See: David F. Patton, Cold War Politics in Post War Germany (London: Palgrave Macmillan, 1999).

${ }^{17}$ George C. Herring, From Colony to Superpower: U.S. Foreign Relations since 1776 (The Oxford History of the United States) (London \& Oxford: Oxford University Press, 2008), 770 772.

${ }^{18}$ See: Robert Mark Spaulding, Osthandel and Ostpolitik: German Foreign Trade Policies in Eastern Europe from Bismarck to Adenauer (Oxford \& New York: Berghahn Books Inc., 1997). 
ues between the two countries ${ }^{19}$. Since the early 1960s, several bilateral cultural agreements were signed, and the FRG initiated an intensive cultural-academic program in this country. In 1962, for example, Yugoslavia was the first socialist country to initiate university-level partnerships with West Germany; a YugoslavGerman conference was organized annually in Dubrovnik, professors from both countries visited each other, and the access of Yugoslav citizens to study and research trips and to academic events in the FRG was made easier ${ }^{20}$. Of course, the rapprochement between the two countries could only have taken place in the context of Tito's policy of neutrality initiated after 1948 and due to the fact that this socialist state was not part of the Central-Eastern European military alliance formalized in 1955 by the Warsaw Pact. Therefore, the distancing from the foreign policy pursued by the Soviet Union and the lack of political and diplomatic obligations towards the GDR allowed Yugoslavia to successfully cooperate with the West, and especially with the FRG. As the West German authorities noticed in 1971, "After its detachment from the ruling system of the Soviet Union, Yugoslavia also opened up culturally to the West to such an extent that there is now a network of lively relations with scientific institutions in the Western world"21.

Sporadic academic relations had existed since the 1950s between the FRG, on the one hand, and Poland and Hungary, on the other. Especially in the case of Poland, there was a cultural collaboration with West-German cultural and academic institutions throughout the Cold War, in spite of the territorial disputes between the two countries ${ }^{22}$. It intensified during the following decades, starting with 1970. In December 1970, the FRG and Poland established diplomatic relations. This positive dynamic pleased even the authorities in Bonn, who were, in general, constantly dissatisfied by the level of cooperation with the countries of the Eastern bloc. On October 10, 1970, for example, an agreement was signed between DAAD, several offices for international collaboration at West German

${ }^{19}$ Richard West, Tito and the Rise and Fall of Yugoslavia (New York: Carroll \& Graf Publishers, 1995), 271.

${ }^{20}$ Politisches Archiv des Auswärtigen Amts Berlin (PAAA Berlin), AV Neues Amt, Folder B 94, File no. 504, January 17, 1972, p. 2.

${ }^{21}$ PAAA Berlin, AV Neues Amt, Folder B 94, File no. 504, January 15, 1971.

${ }^{22}$ See Dieter Bingen, „Der lange Weg der „Normalisierung”. Die Entwicklung der Beziehungen zwischen der Bundesrepublik Deutschland und Polen 1949-1990", in Wolf-Dieter Eberwein, Basil Kerski (eds.). Die deutsch-polnischen Beziehungen 1949-2000. Eine Werte- und Interessengemeinschaft? (Opladen: Leske + Budrich Verlag, 2001), 35-59; Dieter Bingen, Die Polenpolitik der Bonner Republik von Adenauer bis Kohl 1949-1991 (Baden-Baden: Nomos, 1998); Mieczysław Tomala, Deutschland von Polen gesehen. Zu den deutsch-polnischen Beziehungen 1945-1990 (Marburg: Schüren Verlag, 2000); Debra J. Allen, The Oder-Neisse Line: The United States, Poland, and Germany in the Cold War (Westport \& London: Praeger, 2003). 
universities, and the Polish Academy of Sciences, with the support of the Polish Ministry of Foreign Affairs and the Ministry of Education ${ }^{23}$. This led to an intense exchange of students and researchers between the two countries ${ }^{24}$.

On the contrary, the academic collaboration with Hungary was difficult and sporadic. Although initiated rather early, the reports from the German Foreign Ministry ${ }^{25}$ show that it was controlled excessively by the Hungarian authorities, taking place mainly in those areas where Hungary intended to import technology and knowledge from the West, first of all in technical fields and in agriculture $^{26}$. The difficulties of this cooperation were evident in the slowness with which Hungary and the FRG managed to establish diplomatic relations: this took place as late as December 21, $1973^{27}$.

The academic collaboration with Bulgaria officially started in 1966, although for the first several years nothing happened, besides declarations and plans $^{28}$. As in the case of most other socialist states, the relations were limited, on the one hand, by the lack of political and diplomatic links between the two countries and, on the other hand, especially in the case of Bulgaria, by the very close connection it had with East Germany: "The position of the GDR in Bulgaria is so dominant, especially in the cultural-political area, and focused only on representation, that such agreements [on the cooperation between Bulgarian and West German higher education institutions] will surely cause disapproval in East Berlin"29. Besides, Bulgaria was known as the "most loyal ally" and satellite of the USSR ${ }^{30}$. In addition, the ideological divergences between the two

${ }^{23}$ PAAA Berlin, AV Neues Amt, Folder B 94, File no. 504, January 18, 1971.

${ }^{24}$ On the Polish-West German relations see Dominik Pick, „Zwischen offiziellem Protokoll und subversiver Tätigkeit. Polnisch-westdeutsche gesellschaftliche Kontakte 1972-1981", in „Schleichwege”: Inoffizielle Begegnungen sozialistischer Staatsbürger zwischen 1956 und 1989, ed. Jerzy Kochanowski, Włodzimierz Borodziej and Joachim von Puttkamer (Jena: Böhlau Verlag, 2010), 275-290.

${ }^{25}$ PAAA Berlin, AV Neues Amt/Bukarest, File no. 13437.

${ }^{26}$ PAAA Berlin, AV Neues Amt, Folder B 94, File no. 498.

${ }^{27}$ For more details on Hungary's relations with the West during this period, see: László Borhi, Hungary in the Cold War, 1945-1956: Between the United States and the Soviet Union (Budapest \& New York: Central European University Press, 2004); Anikó Macher, "Hungarian Cultural Diplomacy, 1957-1963: Echoes of Western Cultural Activity in a Communist Country", in: Jessica C. E. Gienow-Hecht, Mark C. Donfried (eds.). Searching for a Cultural Diplomacy, 75-108.

${ }^{28}$ PAAA Berlin, AV Neues Amt, Folder B 94, File no. 504, January 17, 1972, p. 3

${ }^{29}$ PAAA Berlin, AV Neues Amt, Folder B 94, File no. 504, January 14, 1971, p. 2.

${ }^{30}$ Jordan Baev, "The Establishment of Bulgarian-West German Diplomatic Relations within the Coordinating Framework of the Warsaw Pact”, in Journal of Cold War Studies, Volume 18, Issue 3, Summer 2016, p. 161. 
countries made a real academic collaboration possible only in technical fields and in natural sciences: again, a situation similar to other socialist states ${ }^{31}$. The initiation of diplomatic relations with Bulgaria was delayed until December 1973, despite West German hopes and long negotiations in this sense.

The FRG's cooperation with Romania was, for a short period, a source of great hope for the authorities in Bonn. After Nicolae Ceaușescu came to power, Romania was the first country in the Eastern bloc to establish diplomatic relations with the FRG: on January 31, 1967, the West German Embassy was opened in Bucharest ${ }^{32}$. This set a precedent, as in the following years the other communist states would follow suit. The political rapprochement was accompanied by an intensifying cultural and academic collaboration: in 1966 a first Romanian scholar was able to travel and pursue research in the FRG, and in 1967 negotiations started on the signing of partnerships between Romanian and West German universities. There was a period of several years (19671971) when Romania was FRG's closest partner in the Eastern bloc. However, this cooperation soon showed its limits. Ceaușescu's ideological shift in the 1970s (the 1971 July theses $^{33}$, decree no. 95 of July 29, 1975 ${ }^{34}$, and the reorientation of Ceaușescu's foreign policy towards Africa, Asia, and Latin America), the severe economic crisis and the increased ideological control during the 1980s led to the "freezing" of the relations between the two countries ${ }^{35}$. The

${ }^{31}$ PAAA Berlin, AV Neues Amt, Folder B 94, File no. 504, January 14, 1971.

${ }^{32}$ See Vasile Buga, Sub lupa Moscovei. Politica externă a României, 1965-1989 (Bucharest: Institutul Național pentru Studiul Totalitarismului, 2015), 11-38. Also see: România-Republica Federală Germania. Începutul relațiilor diplomatice. Volume I, 1966-1967, ed. Claudiu Florian, Dumitru Preda, Ottmar Trașcă (Bucharest: Editura Enciclopedică, 2009); Ion M. Anghel, „Stabilirea relațiilor diplomatice între România și Republica Federală a Germaniei,” în Pagini de diplomația României, vol. I (Asociația ambasadorilor și diplomaților de carieră din România) (Iași: Editura Junimea, 2009); Mioara Anton, „Stabilirea relaţiilor diplomatice româno-vest-germane, 31 ianuarie 1967”, în Arhivele Totalitarismului, nr. 1-2/2008 (Bucharest: Institutul Naţional pentru Studiul Totalitarismului, 2008); Anneli Ute Gabanyi, „Stabilirea relațiilor diplomatice între Republica Federală a Germaniei și România în anul 1967”, în România. Supraviețuire și afirmare prin diplomație în anii războiului rece. Vol. 3. (Târgoviște: Editura Cetatea de Scaun, 2014).

33 "Law 23 regarding the defense of the state secret in the Socialist Republic of Romania", published in the Official Bulletin no. 157, December 17, 1971, which tightened ideological control and strenghened the propaganda.

34 "Decree 95 regarding studying, specializing and obtaining a $\mathrm{PhD}$ abroad", published in the Official Bulletin no. 83, July 30, 1975, which imposed very restrictive criteria for being allowed to travel abroad.

${ }^{35}$ See Irina Nastasă-Matei, „Academic Migration and Cultural Diplomacy during the Cold War. Humboldt Fellowships for Romania in the Context of Eastern Europe", in History of Communism in Europe, Vol. 9 (2018): 141-144. 
academic collaboration was particularly intense in the fields of agricultural research and nuclear energy, especially during the 1970s. ${ }^{36}$ The most prestigious Romanian universities - in Cluj, Iasi and later Bucharest - welcomed lecturers of the German language from the $\mathrm{FRG}^{37}$, while a West German Cultural Institute was to be established in Romania according to the "Agreement for cooperation in the field of scientific research and scientific development between the government of the SRR and the government of the FRG," signed in 1973. The Institute only opened in Bucharest in 1979, yet it was the first Goethe Institute established in the capital of a Communist country ${ }^{38}$. At the same time, Romania's academic and cultural relations with the GDR were not very intensive: Romania was the only country of the Warsaw Pact where the GDR had not opened any cultural institute ${ }^{39}$ and where there was no German lectureship from East Germany. Although dissatisfied with the stagnation of the bilateral academic relations, West German embassy officials in Bucharest acknowledged, in 1982, that

"When looking through the cultural-political annual reports from our Eastern bloc embassies from 1981, I had the impression that, despite all the mishaps, harrassment and lack of reliability we experienced from the part of the Romanians in Bucharest, this is where the best opportunities for a German cultural policy are to be found. Yugoslavia is an exception here, but this case has no comparative significance, not even in the field of the German language, since here [in Yugoslavia] a German population no longer exists" ${ }^{\prime \prime 0}$.

The relations between the FRG and Czechoslovakia were difficult. Although at the political level there was an urge to build connections with West Germany (and Yugoslavia) as early as $1956^{41}$, the cultural and academic relations were so insignificant that they were barely mentioned in the West German reports regarding the links to Eastern Europe. That was mainly due to the memory of the Munich Agreement of 1938, at least in Czechoslovakia's case, and to the deportation, after the Second World War, of the German minority from the Sudetenland region, in West Germany's case. Student and researcher exchanges did develop, however, and many Czechoslovakians traveled for study or research to West Germany, starting with 1967 and through-

\footnotetext{
${ }^{36}$ PAAA Berlin, AV Neues Amt/Bukarest, File no. 13346.

${ }^{37}$ PAAA Berlin, AV Neues Amt/Bukarest, File no. 13353, February 19, 1974.

${ }^{38}$ PAAA Berlin, AV Neues Amt/Bukarest, File no. 13418, April 21, 1980.

${ }^{39}$ PAAA Berlin, AV Neues Amt/Bukarest, File no. 13419.

${ }^{40}$ PAAA Berlin, AV Neues Amt/Bukarest, File no. 13437, Juni 29, 1982.

${ }^{41}$ See National Archives of the United Kingdom, Foreign Office: Political Departments: General Correspondence from 1906-1966, FO 371/122141.
} 
out the 1970s. This tendency received a great boost around the period of the Prague Spring of $1968^{42}$.

The USSR's relations with the Federal Republic of Germany began with the signing, on August 12, 1970, of a framework agreement known as "the Moscow Treaty"43. This was the official milestone in the beginning of FRG's Ostpolitik. It was the first of the so-called "Ostverträge." This treaty allowed the establishment of political, economic, cultural and diplomatic relations between the two countries. It was followed, in 1972, by the signing of an "Agreement between the FRG and the USSR on cultural cooperation" ${ }^{\prime 4}$. The agreement emphasized the Soviet interest mainly in scientific collaboration, more specifically, in the field of natural sciences, so that the USSR's technological and agricultural development might benefit from this exchange. This was a part of the Soviet change in strategy regarding the access to scientific and technological knowledge: it evolved from the unsuccessful attempts at technological espionage in the 1950s, to procurement of advanced technology from the West through collaboration and, more exactly, through the scientists', researchers' and students' exchanges starting from the late $1960 \mathrm{~s}^{45}$.

Actually, this dynamic was something common in the relations between most of the communist countries: trying to get technology from the West through academic exchanges and allowing collaboration only in those scientific fields where the communist regimes might have an immediate interest. By contrast, for the FRG authorities it was the West German presence in these countries - through institutes, lectureships, students and academics, and through various cultural productions - that mattered. It underscored the FRG's competition with East Germany and served to highlight their cultural prominence and their status as an acknowledged German state in this part of the world.

Although the USSR's cultural and academic collaboration with the West unfolded especially in the Soviet relations with West Germany and Finland ${ }^{46}$, and in spite of fulfilling the formal requirements for this collaboration (based on the stipulations of the agreements), the actual extent of collaboration between the USSR and West Germany remained limited. Ideological barriers, as well as

\footnotetext{
42 "New programme initiatives for the promotion of research in Central and Eastern Europe”, in Alexander-von-Humboldt Stiftung / Foundation, Jahresbericht / Annual Report 2000, p. 14.

${ }^{43}$ Treaty between the Federal Republic of Germany and the Union of Soviet Socialist Republics [“Moskauer Vertrag”], August 12, 1970.

${ }^{44}$ PAAA Berlin, AV Neues Amt, Folder B 94, File no. 498.

${ }^{45}$ Sari Autio-Sarasmo, "Knowledge through the Iron Curtain: Soviet Scientific-Technical Cooperation with Finland and West Germany", in Sari Autio-Sarasmo and Katalin Miklossy, eds., Reassessing Cold War Europe (London: Routledge Studies in the History of Russia and Eastern Europe, 2011), 66-82.

${ }^{46}$ Autio-Sarasmo, "Knowledge through the Iron Curtain."
} 
the USSR's strict controls and rigid planning policy prevented a full-scale and consistent cooperation.

Most instances of cultural and academic collaboration between the FRG and the countries of the Eastern bloc were initiated by various West German institutions even prior to the development of diplomatic relations with these countries, and before there was a coherent German official policy in this respect. The DAAD (Deutscher Akademischer Austauschdienst - The German Academic Exchange Service), in particular, was involved in planning student and youth exchanges since the mid 1960s, while in the same period the Alexander von Humboldt Foundation started to advertise its offers in Eastern Europe and to invite former fellows from the region to reconnect with the Foundation ${ }^{47}$. In 1970 these two institutions joined a consortium, together with the German Research Foundation (Deutsche Forschungsgemeinschaft), the Max Planck Society (Max-Planck-Gesellschaft) and the German Rectors' Conference (Hochschulrektorenkonferenz) ${ }^{48}$ in a bid to build partnerships between universities from the FRG and those from the Soviet bloc. An Eastern European Partnerships Commission (Kommission für Osteuropäischen Partnerschaften) was established to coordinate policy in this respect ${ }^{49}$. The first agreement of this kind was signed on May 9, 1970, between the Karlsruhe Institute of Technology and the Technical University of Budapest. It was soon followed by many other similar examples, for which it served as a model.

The university partnerships were financed exclusively by West Germany, with most of the funds coming from the Foreign Ministry (Auswärtiges Amt AA), which was immediately indicative of the fact that the FRG was perceiving this type of academic collaboration as a part of its "foreign affairs". The political significance of these partnerships was in fact acknowledged by the German authorities. In December 1970, when the representatives of the AA and the Rectors' Conference discussed this issue, "the participants agreed that university partnerships with Eastern European universities and research institutions are of considerable importance given the current political situation (author's empahsis) and that they should be promoted as far as possible" ${ }^{\text {50 }}$. Similarly, in October 1971, the director of the German Research Foundation stated that

\footnotetext{
${ }^{47}$ Irina Nastasă-Matei, „Academic Migration,” 151.

${ }^{48}$ The German Rectors' Conference (Hochschulrektorenkonferenz) is an organization comprising universities and higher education institutions. It was established in 1949 in West Germany.

${ }^{49}$ PAAA Berlin, AV Neues Amt, Folder B 94, File no. 504.

${ }^{50}$ PAAA Berlin, AV Neues Amt, Folder B 94, File no. 504, December 23, 1970.
} 
"There is certainly no doubt that the cultural and scientific relations with the countries of Eastern Europe are characterized by special political nuances. This is due to the fact that the scientific institutions in Eastern Europe cannot act as freely as those in our country, but are, to a considerable extent, dependent on the wishes and instructions of their governments. However, one should not overlook the fact that, of course, a political interest in these questions cannot be denied on our part as well, that cultural and scientific relations are to be classified as a subdivision of the overall field of politics and that they are of considerable significance, alongside economic and political issues" ${ }^{\prime \prime}$.

The political stakes involved in the academic relations with Eastern Europe were also obvious from the West German reports concerning Romania:

"In our opinion, there is an elementary German interest in promoting the exchange of scientifically qualified people between the two states by all means possible, because these are propagators. If, for certain internal reasons, the Romanian authorities wish to choose the less official way of engaging into partnerships in order to increase their exchange rates, then, in my opinion, this opportunity should be used, taking into account the difficulties that Romania may encounter within the socialist bloc due to an obviously important exchange with the FRG. Therefore, in the interest of a stronger representation of the FRG, especially given its competition with the GDR, the Embassy asks that the applications of the Rectors' Conference and the DAAD respectively, for funding the exchange projects at the partnership level be supported financially"52.

Unsurprisingly, the academic relations between the FRG and the countries of the Eastern bloc soon displayed their limits. In the eyes of the German authorities, the university partnerships could not function properly because the universities from the Eastern bloc did not enjoy any autonomy and were completely dependent on the state. Moreover, as previously shown, the scientific exchanges took place only in specific fields ${ }^{53}$, at the sole choice of the Eastern partners. The exchanges involved, in particular, technical disciplines, medicine, physics, chemistry, and agriculture. These difficulties were summed up by Werner Heisenberg, at that time president of the Alexander von Humboldt Foundation, in a report he submitted to Hans Georg Steltzer, the director of the cultural department within the AA:

"In my opinion, aspects of a purely political nature are to be observed, first of all, in the contractual agreements with the universities from Eastern Europe. In comparison to Western European conditions, the Eastern European universities are, to a much greater extent, representatives of the state and of its ideology. There is no - or only a very modest degree of - autonomy with regard to the state, although

\footnotetext{
${ }^{51}$ PAAA Berlin, AV Neues Amt, Folder B 94, File no. 504, October 29, 1971.

${ }^{52}$ PAAA Berlin, AV Neues Amt, Folder B 94, File no. 520, May 18, 1972.

${ }^{53}$ PAAA Berlin, AV Neues Amt, Folder B 94, File no. 498.
} 
it is inherent in the universities of the Federal Republic. That is why the contractual relations between universities in Germany and Eastern European universities have an eminently foreign policy dimension. Under these circumstances, it is conceivable that partnerships in the case of the Eastern Europeans are not always used solely to promote scientific relations. It is possible that, through the partnership agreements, an attempt is made to display, at least, some general political claims. (...)

The Eastern European partners would like to gain access to the research developments that are currently taking place in the technical universities of the FRG, especially in the field of technology, by concluding partnership agreements.

Furthermore, it is all too well known how easily this special promotion of partnership agreements with Eastern European universities could be misunderstood by the latter states as a subversive attempt of "imperialism" and interpreted accordingly. This danger can only be countered if we do not grant any particular cultural-political funding for Eastern European countries, but rather embed them into a larger international context" ${ }^{\prime \prime}$.

The organization of youth exchanges and summer trips for students also encountered difficulties. In the case of all Eastern European countries these contacts were hindered by the strict control exercised by the communist youth travel services. If initially the requirements for receiving exit permits in order to visit West Germany were looser, the numerous cases of escapes by the youth who decided not to return to their socialist country of origin led to a more rigid policy in this respect and to difficulties in obtaining the exit permits ${ }^{55}$. The efforts made by the Germans to develop a less official, less formalized exchange in this respect remained unsuccessful, as the controls continued to tighten throughout the 1970s and the 1980s, while the number of exit permits became smaller and smaller. The desire of the communist authorities to plan everything in advance was also an important impediment in this regard. Ultimately, it was mostly the German youth who visited Eastern Europe, with their Eastern European counterparts being denied passports and visas by their own governments ${ }^{56}$. That might have been a pleasant experience for the German teens, but it did not meet the expectations of the West German authorities concerning the role this kind of exchanges should play. This fact was proven by an official letter from the AA sent to the West German embassies in Moscow, Bucharest and Belgrade and to the West German commercial agencies in Warsaw, Prague, Budapest and Sofia:

"Inquiries from youth organizations and groups, as well as reports on trips made, show the difficulty of finding concrete partners for a collaboration with the youth in Eastern Europe. The state travel agencies only organize group contacts which,

\footnotetext{
${ }^{54}$ PAAA Berlin, AV Neues Amt, Folder B 94, File no. 504, August 16, 1971.

${ }^{55}$ PAAA Berlin, AV Neues Amt, Folder B 94, File no. 498, November 13, 1969.

${ }^{56}$ PAAA Berlin, AV Neues Amt, Folder B 94, File no. 498, November 13, 1969.
} 
due to their time limitation and rigorous organization, do not provide any possibility for actual mutual connection. Therefore, the study trips often take on a touristic character, which is only partially satisfactory for the German young people involved and does not fulfill the purpose of the operation, which is the exchange of views between young people with the aim of raising European awareness" ${ }^{\prime \prime 7}$.

The many cases of escape were also to blame for the vigilence of the authorities from the communist states with regard to letting their citizens travel to the West. In 1969, for example, 13 out of a group of 28 Romanian young people who visited West Germany at the invitation of the German Society for International Youth Exchange (Deutschen Gesellschaft für Internationalen Jugendaustausch) escaped from the hotel where they were staying, in the small Bavarian city of Füssen, and demanded political asylum. The German media reported that it was the third group of Romanian youth visiting Füssen, and that there were at least 10 people in each of the first two groups who had also decided to remain in the West ${ }^{58}$.

The authorities were exceptionally cautious in allowing the students, researchers, and professors to travel to West Germany for longer periods, for example, in the framework of a scholarship or a fellowship. The Eastern European authorities wished to decide themselves, without any involvement of the funding institution (most often, the DAAD or the Humboldt Foundation), on who were the persons allowed to be sent to specialize or study abroad. They supported people with a certain political profile, mainly those loyal to the communist regime or party members, and, in some cases, secret police informants. In Romania, for example, the future invited scholars and fellows had to obtain permision from the Communist Party, as well as from the Securitate, in order to be granted the exit permits ${ }^{59}$. Moreover, the personal connections of the applicants seemed to weigh more than their professional profile and their qualifications. The Germans denounced several cases of corruption and nepotism ${ }^{60}$. This led to a hybrid application system: there were both so-called „direct applications” for a German fellowship and „indirect applications”, the latter being arranged by the scientific institutions and the universities from the communist countries. The consequences of this system were paradoxical: the applicants supported by their states had much less success in getting a fellowship, since their advantage was not their professional qualification and expertise, but rather their prior po-

\footnotetext{
${ }^{57}$ PAAA Berlin, AV Neues Amt/Bukarest, File no. 13316, February 10, 1970.

${ }^{58}$ Münchner Merkur, 28.08.1969, apud PAAA Berlin, AV Neues Amt, Folder B 94, File no. 575.

${ }^{59}$ Irina Nastasă-Matei, „Academic Migration,” 153.

${ }^{60}$ PAAA Berlin, AV Neues Amt, Folder B 94, File no. 498, November 13, 1969; PAAA Berlin, AV

Neues Amt/Bukarest, File no. 13328, January 20, 1970.
} 
litical conduct and their connections. The direct applicants were more likely to receive an invitation to pursue their study and research in West Germany, but they were frequently refused the exit visa by their own states. The reasons for this refusal could be manifold: it could happen for political reasons, such as "unhealthy origin”, lack of loyalty or suspect political activity before the end of World War II. It could also occur due to the applicant's choosing of what was perceived to be an unimportant field of research, or simply due to a person's bypassing the formalities and submitting a direct application (the submission itself was problematic, since the papers had to be smuggled out of the country) ${ }^{61}$. The fact that many scholars did not return was also a factor hampering a more intensive collaboration of this type.

\section{The Humboldt fellowships \\ for Eastern Europe during the Cold War}

The Alexander von Humboldt Foundation was - and still is - the most important and lasting German foundation supporting research and international exchange in virtually every field of theoretical study. Its long history developed in three stages. Between 1860 and 1923 it was devoted to supporting research abroad exclusively for German scholars. After being re-established in 1925, it shifted its focus to supporting mostly foreign scholars who undertook research in Germany, but it was dissolved in 1945 due to the disintegration of Nazi Germany and also because of the role it had played in the Nazi propaganda apparatus $^{62}$. After 1953, it was recreated in West Germany with the purpose of fostering and supporting scientific and technological development, international academic exchanges, and the FRG's cultural diplomacy.

From 1953 onward, the Alexander von Humboldt Foundation offered very generous and prestigious fellowships to postdoctoral researchers and to established academics and scientists. The funds came mainly from federal sources, i.e., the Ministry of Foreign Affairs and the Ministry of Education. Only a very small percentage of the budget came from private donations. The organization and functioning of the Foundation are politically independent; the institution enjoys administrative autonomy and uses a series of independent commissions

${ }^{61}$ Irina Nastasă-Matei, „Academic Migration,” 152. See, for example: PAAA, AV Neues Amt, Folder Bukarest, File no. 13328, 20 January 1970; File no. 13348, 21 February 1972; File no. 13348, 19 March 1972; File no. 13353, 24 March 1976.

${ }^{62}$ See Holger Impekoven, Die Alexander von Humboldt-Stiftung und das Ausländerstudium in Deutschland 1925-1945. Von der „geräuschlosen Propaganda” zur Ausbildung der „geistigen Wehr” des „Neuen Europa” (Göttingen: Vandenhoeck\&Ruprecht Verlag \& Bonn University Press, 2013). 
for the scientific assessment and analysis of the applications. The criteria for granting the fellowships are based on academic excellence and do not take into account any quotas.

Although the Foundation is politically independent, the distribution of fellowships usually reflected the various developments in international relations and the shifting orientation of Germany's foreign policy. A strong German influence and good diplomatic relations with a certain country meant that a high number of applications were submitted from that country, which led to a high number of fellowships awarded. First, the potential fellows needed to become familiar with the Foundation's offers; second, they had to be able to send their applications, and, in case of success, to be able to travel to the FRG; and third, the Foundation should have been able to respond financially to the increasing rate of demand by requesting more funding from the government, in order to maintain its success rate. Consequently, the Foundation's budget increased constantly: there were 1502 fellowships awarded between 1953 and 1963. The number almost doubled between 1964 and 1973 (growing to 2948 fellowships), doubling again during the next decade, with 4567 fellowships awarded between 1974 and 1983 (see Table I). The number of applications received also went up proportionally, so that the overall success rate increased only slightly.

Since the Foundation was involved from the beginning in developing the framework for the academic relations with Eastern Europe - as shown above, it was an important actor in establishing university partnerships between the FRG and the countries of the Eastern bloc - it was only natural that Humboldt fellowships would be also awarded to people from this region. Scholars from Yugoslavia could benefit from this opportunity from the very beginning. Two Humboldt fellowships were offered to two Yugoslav academics in $1954 .{ }^{63}$ This was possible only in the context of Tito's neutrality policy pursued after 1948 and due to Yugoslavia's good relations with the FRG. The collaboration with the other socialist countries began somewhat later. Although there were very few applications from Poland and Hungary, enjoying the unusually high success rate of over $60 \%$, only from the mid 1960s one can speak about a consistent access of people from Eastern Europe to this academic opportunity. This coincides with the establishment of economic and political relations between the FRG and the states of the Eastern bloc, which was followed by the development of academic links, as described above. Only in a more formalized context, and only after the Foundation had secured the collaboration of the socialist governments, could candidates from Eastern Europe more easily apply and, if successful, travel to West Germany.

${ }^{63}$ Humboldt Stiftung, Alexander-von-Humboldt Stiftung 1953-1983 (Bonn, 1983), 123. 
In what follows, the reports and statistics put together by the Foundation itself are the main sources for determining the number of fellowships awarded to people from Eastern Europe and the evolution of the relations with each of the socialist countries. These reports and statistics were published annually, but also at the end of each decade of the Foundation's reestablishment in 1953. I used mostly the report drawn up in 1993, since it comprised the entire period on which my article focuses. I also consulted the report from 1983, which offered plenty of details regarding the specific countries of origin of the fellows.

These statistics show clearly that the fellows from the Eastern bloc made up an important percentage among the recipients of the Humboldt fellowships, particularly starting with the second decade of the Foundation's reestablishment, from 1964 onward (see Table 1). Not only was the number of applications from this region high, but so was their success rate. In some periods, the success rate was above $40 \%$, which was much higher than the similar rate for people coming from established Western academic milieus. This fact highlights, once again, the FRG's - and the Foundation's - aim to support people from that region. Among the top 10 countries sending the most fellows to the Foundation between 1953 and 1989, three were Eastern European (Poland in $4^{\text {th }}$ place, Yugoslavia in $5^{\text {th }}$ and Czechoslovakia in $7^{\text {th }}$ place $)^{64}$.

The statistics also reflect the fluctuations regarding the number of Humboldt fellows from specific Eastern European countries. This can be directly linked to internal political developments in particular countries, to various changes in the balance of international relations during the Cold War, as well as to the evolution of each country's relations with the FRG. This shows that the political factor had a decisive impact on the number of applications, and on the success rate. Although it was less obvious from the statistics, the reports also highlighted the actual ability of East European scholars to visit West Germany. The political implications were fully acknowledged by the Foundation's officials in later reports:

"The Foundation is politically neutral. It sponsored scholars from Central and Eastern Europe long before the establishment of diplomatic relations: from (the former) Yugoslavia - since 1954, from Poland and Hungary since 1959, from Bulgaria since 1964, from (the former) Czechoslovakia since 1965, from Romania since 1966 and from the (former) Soviet Union since 1970. About 2,500 scholars from Central and Eastern Europe had been sponsored by 1989, which amounts to one fifth of all Humboldtians invited by that time.

${ }^{64}$ Kurt-Jürgen Maaß, Bridges for Research. Range and Impact of the Humboldt Foundation (Berlin: Alexander von Humboldt Foundation, 1989), 36. 
However, academic exchanges were frequently influenced by political events. During the "Prague Spring," in the late 1960s, Czechoslovakia was at the top of the Humboldt Foundation's sponsorship statistics for two years. After that, this number quickly dropped to zero. At the beginning of the 1970s, during the "period of relaxation", many scholars from Romania came to Germany, but almost none arrived during the subsequent political "cold war". By 1988, only 76 research fellowships had been granted to scholars from the former Soviet Union"65.

Table 1: Humboldt fellows from various countries, 1953-1993 ${ }^{66}$

\begin{tabular}{|l|c|c|c|c|c|c|c|c|c|c|c|c|}
\hline \multirow{2}{*}{ Country } & \multicolumn{3}{|c|}{$1953-1963$} & \multicolumn{3}{c|}{$1964-1973$} & \multicolumn{3}{c|}{$1974-1983$} & \multicolumn{3}{c|}{$1984-1993$} \\
\cline { 2 - 14 } & A & B & $\%$ & A & B & $\%$ & A & B & $\%$ & A & B & $\%$ \\
\hline Romania & - & - & - & 472 & 164 & 34,7 & 177 & 49 & 27,7 & 181 & 38 & 21 \\
\hline Bulgaria & 1 & - & - & 305 & 111 & 36,4 & 236 & 74 & 31,4 & 447 & 86 & 19,2 \\
\hline $\begin{array}{l}\text { Czechoslo- } \\
\text { vakia }\end{array}$ & 1 & - & - & 734 & 283 & 38,6 & 64 & 28 & 43,8 & 76 & 27 & 35,5 \\
\hline $\begin{array}{l}\text { Czechoslo- } \\
\text { vak Republic }\end{array}$ & & & & & & & & & & 217 & 63 & 29 \\
\hline Poland & 13 & 8 & 61,5 & 286 & 118 & 41,3 & 1176 & 434 & 36,9 & 1898 & 400 & 21,1 \\
\hline USSR & - & - & - & 5 & 2 & 40 & 78 & 48 & 61,5 & 10 & 7 & 70 \\
\hline Russia & - & - & - & - & - & - & - & - & - & 1057 & 345 & 32,6 \\
\hline Hungary & 26 & 17 & 65,4 & 134 & 57 & 42,5 & 211 & 93 & 44,1 & 411 & 175 & 42,6 \\
\hline Yugoslavia & 260 & 88 & 33,8 & 642 & 178 & 27,7 & 254 & 76 & 29,9 & 260 & 54 & 20,8 \\
\hline France & 65 & 19 & 29,2 & 111 & 44 & 39,6 & 158 & 72 & 45,6 & 392 & 189 & 48,2 \\
\hline Great Britain & 72 & 35 & 34,7 & 226 & 95 & 42 & 369 & 173 & 46,9 & 300 & 152 & 50,7 \\
\hline USA & 168 & 50 & 29,8 & 764 & 280 & 36,6 & 1302 & 674 & 51,8 & 1136 & 594 & 52,3 \\
\hline Egypt & 264 & 68 & 25,8 & 484 & 103 & 21,3 & 487 & 88 & 18,1 & 339 & 41 & 12,1 \\
\hline India & 567 & 121 & 21,3 & 774 & 177 & 22,9 & 2256 & 450 & 19,9 & 1724 & 272 & 15,8 \\
\hline China & - & - & - & - & - & - & 546 & 172 & 31,5 & 1149 & 323 & 28,1 \\
\hline Taiwan & 69 & 16 & 23,2 & 76 & 15 & 19,7 & 75 & 27 & 36 & 49 & 10 & 20,4 \\
\hline Japan & 520 & 247 & 47,5 & 1003 & 433 & 43,2 & 1281 & 593 & 48,7 & 921 & 438 & 47,6 \\
\hline Argentina & 178 & 65 & 36,5 & 142 & 48 & 33,8 & 161 & 60 & 37,3 & 171 & 69 & 40,4 \\
\hline Total & $\mathbf{4 7 4 6}$ & $\mathbf{1 5 0 2}$ & $\mathbf{3 1 , 6}$ & $\mathbf{8 8 6 0}$ & $\mathbf{2 9 4 8}$ & $\mathbf{3 3 , 3}$ & $\mathbf{1 2 6 3 2}$ & $\mathbf{4 5 6 7}$ & $\mathbf{3 6 , 2}$ & $\mathbf{1 5 4 5 6}$ & $\mathbf{4 8 9 7}$ & $\mathbf{3 1 , 7}$ \\
\hline
\end{tabular}

A - Number of applications

B - Number of fellowships awarded

$\%$ - Success rate

Yugoslavia was very well represented among the recipients of the Humboldt fellowships. Its collaboration with the Foundation started already in 1954 and intensified from 1960 onward. In 1959, for example, 2\% of the total Humboldt

65 "New programme initiatives for the promotion of research in Central and Eastern Europe", in Alexander-von-Humboldt Stiftung / Foundation, Jahresbericht / Annual Report 2000, 14.

${ }^{66}$ Humboldt Stiftung, Alexander-von-Humboldt Stiftung 1953-1993. 40 Jahre im Dienst von Wissenschaft und Forschung, 279-283. 
fellows came from Yugoslavia (3 people), while in 1960 and 1961 over 8\% (11, and, respectively, 16 fellows were of Yugoslav origin. By 1962, this number increased to $12.3 \%$ ( 22 fellows). The tendency remained similar throughout the 1960s: between 20 and 30 Yugoslav fellows were admitted each year, representing around $10 \%$, or higher, of the total number of fellowship recipients. The numbers started to drop slowly in the 1970s (amounting to 5-10 fellows per year, with a maximum of 15 in 1971, i.e., 1-3\% of the total) and decreased dramatically in the 1980s, to just a few Yugoslav fellows per year (around 1\%). The reason for this decrease is not clear, but it might have been caused by the economic crisis unfolding during that era, which had hit Yugoslavia particularly hard.

From among the Yugoslav recipients, 53\% were working in the field of natural sciences (mostly medicine, with some also working in chemistry and pharmacy). $35 \%$ were specialized in the humanities, and $12 \%$ were engineers. Especially surprising is the significant number of Yugoslav scholars coming to West Germany who specialized in the humanities. Their proportion was much higher than the average percentage. Among these scholars, the majority was studying philosophy (apparently, a long-standing tradition). Many of them were pursuing careers in law, letters, German studies and other foreign languages ${ }^{67}$. Most of the Yugoslav Humboldt fellows were tenured at institutions based in three important Yugoslav academic centers: Zagreb, Belgrade, and Ljubljana ${ }^{68}$.

Poland was generally very close to Germany and to German culture. Traditionally, the modern Polish elite had been educated at German institutions of higher education. The $20^{\text {th }}$ century was no exception in this respect: up until Word War II, Polish students, for example, made up the largest group of foreign students at German universities. The events of World War II, however, put a major strain on the Polish-German relations. Poland's collaboration with West Germany proved to be very difficult in the first postwar decades, intensifying only after 1970 .

The number of Polish Humboldt fellows was relatively small (corresponding to a small number of applications) up until 1971. It amounted to 1-2 fellows a year in the early 1960s, growing to 5-9 fellows per year between 1964 and 1971. Then, their number started to increase significantly, to about 30, 40, and even 50 Polish fellows per year during the next decades. In some cases, Polish academics received more than $10 \%$ of the total number of fellowships awarded. This fact made Polish scholars one of the most well represented groups of recipients. They were surpassed only by academics from countries such as Japan,

\footnotetext{
${ }^{67}$ Humboldt Stiftung, Alexander-von-Humboldt Stiftung 1953-1983, 122-123.

${ }^{68}$ Maaß, Bridges for Research, 38.
} 
India and the US, which were the Foundation's closest collaborators. Poland thus was the most broadly represented socialist country in the overall activity of the Humboldt Foundation.

Most of the Polish fellows were working in technical fields (engineers amounted to 20\%). Many others were active in the medical field (14\%), chemistry/pharmacy (11\%), physics, and astrophysics $(10 \%)^{69}$. The number of scholars from the humanities who received (and were able to accept) these grants was surprisingly high: 1/3 of the Polish Humboldt fellows during the Cold War were researching, while in West Germany, in the fields of history and law. This trend was atypical for the socialist countries which, in general, preferred to benefit technologically and scientifically from the more developed knowledge available in the West. Probably, the long-shared history between the two countries especially contributed to the unusually high number of Polish historians who had received the support of the Foundation. Most of the Polish Humboldt fellows were employed at universities and research institutes in Warsaw, Cracow, and Poznan ${ }^{70}$.

The access of the Hungarian scholars to Humboldt fellowships was one of the broadest among the countries of the Warsaw Pact. The first Hungarian received a fellowship and could travel to West Germany as soon as 1960. 43 Hungarian academics were able to apply between 1960 and 1963, while their success rate was particularly high: $65.4 \%$ were accepted (see Table I). In fact, Hungary had one of the highest success rates of the Humboldt fellowships, averaging at about $45 \%$ throughout the period of the Cold War. The Foundation could also freely collaborate with the Hungarian government. This collaboration reached an impressive level, so that, starting from 1982, Hungarian state institutions ceased to be directly involved in the selection of candidates. All applications received by the Foundation from Hungary were so-called "direct applications". Almost $1 / 3$ of the Hungarian fellows worked in the field of medicine, with many also conducting research in chemistry/pharmacy and biology. Only a minority of the Hungarian fellowship recipients were engineers or worked in technical fields. Very few successful Hungarian candidates were coming from the humanities (mostly from the field of law) ${ }^{71}$.

The Foundation's relations with the Bulgarian fellows followed the same pattern as in the case of most East European countries. The first Bulgarian scholars came to West Germany in the mid-1960s. Their numbers increased

\footnotetext{
${ }^{69}$ Humboldt Stiftung, Alexander-von-Humboldt Stiftung 1953-1983, 130-131.

${ }^{70}$ Maaß, Bridges for Research, 38.

${ }^{71}$ Humboldt Stiftung, Alexander-von-Humboldt Stiftung 1953-1983, 142-143.
} 
year by year until the mid-1970s, when the figures started to drop. Throughout the 1970s, their presence was, on average, of almost 10 fellows/year, which amounted to just under 3\% of the total number of fellows. Also, in the case of the Bulgarians, the majority of fellows took up fellowships in fields belonging to the natural sciences (73\%), mostly medicine and chemistry/pharmacy; $19 \%$ were engineers, and only $8 \%$ were scholars from the humanities (mostly philosophers, linguists, and artists ${ }^{72}$.

Similarly to Bulgaria, Romania developed rather late a stable connection with the Humboldt Foundation. The first two Romanian fellows arrived to West Germany in 1966. They did not apply for the fellowship, but were invited instead $^{73}$, which shows even more clearly the Foundation's interest in also supporting scholars from this country. This practice of inviting the fellows directly was something exceptional. It only happened during the initial period of the cooperation. Later on, the candidates had to submit regular applications, like all the other potential fellows, even when aiming for a second fellowship (i.e., as repeatedly invited scholars).

Throughout the next few years, the number of Romanian fellowship recipients witnessed a continuous growth, up to a maximum of 38 fellows in 1970 . This made the group of Romanian fellows the biggest national cohort that year (they represented $13 \%$ of the total number of fellowship recipients). Subsequently, their number started to sink as quickly as it had grown. By 1975, there were only 9 Romanian Humboldt fellows in West Germany, a number which dropped to 5 in 1977 and 2-4 per year during the following decade ${ }^{74}$. Most of the Romanian fellows, around $60 \%$, were scholars specializing in natural sciences - physics, mathematics, biology. About $20 \%$ were engineers, and the remaining $20 \%$ were specialists in the humanities - German studies, history and philosophy ${ }^{75}$.

1964 was the year when the first Czechoslovak Humboldt fellows arrived to West Germany. The links of the Humboldt Foundation with this country were completely dependent on the international political events and context. Thus, if in 1964 only five Czechoslovak scholars received Humboldt fellowships, in 1965 there were already 22 recipients. During each of the three consecutive years, 1967, 1968 and 1969, the Czechoslovak group constituted around 25\% of the total number of people receiving the fellowships awarded by the Foun-

\footnotetext{
${ }^{72}$ Humboldt Stiftung, Alexander-von-Humboldt Stiftung 1953-1983, 102-103.

${ }^{73}$ PAAA Berlin, AV Neues Amt/Bukarest, File no. 13350.

${ }^{74}$ Irina Nastasă-Matei, „Academic Migration,” 148-154.

${ }^{75}$ Humboldt Stiftung, Alexander-von-Humboldt Stiftung 1953-1983, 132-133.
} 
dation in those years (there were 64 Czechoslovak fellows in 1967, 75 in 1968, and 63 in 1969). This trend coincided with the Prague Spring and marked the liberalization period in the country, during which the Czechoslovaks could apply freely and consequently leave the country. It also showed West Germany's interest in and the Foundation's willingness to provide significant support in order to encourage this democratization process. However, following the Soviet invasion and the reversing of Dubček's reforms, the number of Czechoslovak fellows decreased sharply, to 5 in 1971 and then to only one/year or none during the following decade. The 1980s saw a somewhat better representation of the Czechoslovak scholars, but their number amounted only to several fellows (5-8/year, making up 1-2\% of the total number of fellows).

About $70 \%$ of the Czechoslovak Humboldt fellows during the Cold War were conducting research in the field of natural sciences (mostly in medicine, chemistry/pharmacy and biology), with many also specializing in agriculture and forestry. $24 \%$ of the fellows were scholars in the field of humanities, which was above average. Among them most were historians. Only a handful of fellows were engineers $(6 \%)^{76}$. Most of the Czechoslovak fellows came from Prague and Bratislava ${ }^{77}$.

Unlike its political allies, who managed, especially after the mid 1960s, to develop a significant degree of academic collaboration with the FRG, the Soviet Union was in a very different situation. In spite of the "Moscow Treaty" signed in 1970 and the subsequent agreement regarding the cultural collaboration between the two states, concluded in 1972, the presence of Soviet scholars in West Germany was very restricted and limited throughout the whole period of the Cold War. There were in fact so few Humboldt fellows from the USSR, that the reports of the Foundation do not even provide an analysis regarding the relations with that country, contrary to the case of the other socialist countries from Eastern Europe. Between 1953 and 1991, only 93 scholars from the USSR were able to apply for a Humboldt fellowship, and only 57 received it (see Table 1). Moreover, among the 48 scholars that received it in the decade 1974-1983, only 36 were able to actually travel to West Germany ${ }^{78}$. Consequently, among the 38 Soviet fellows accepted between 1963 and 1983, 11 pursued research in the field of physics; 9 - in biology; 4 - in each of the following fields: history, mathematics and chemistry-pharmacy; 2 - in geology; and one in each of the following disciplines: literature, sociology, mechanics, and electro-technics ${ }^{79}$.

\footnotetext{
${ }^{76}$ Humboldt Stiftung, Alexander-von-Humboldt Stiftung 1953-1983, 138-139.

${ }^{77}$ Maaß, Bridges for Research, 39.

${ }^{78}$ Humboldt Stiftung, Alexander-von-Humboldt Stiftung 1953-1983, 87.

${ }^{79}$ Humboldt Stiftung, Alexander-von-Humboldt Stiftung 1953-1983, 81-82.
} 


\section{Conclusion}

The Alexander von Humboldt Foundation was very successful in its efforts to increase international academic cooperation and to promote science and knowledge, even during complicated times like the period of the Cold War. This article argues that, in spite of granting the fellowships on the basis of the quality of scholars and applications and in spite of the lack of quotas, the awarding of fellowships to people from the states of the Soviet bloc depended on the political relations between West Germany and these countries, on various developments in their domestic policy, as well as on the events occuring on the international arena. Consequently, the Foundation supported West Germany's East-oriented foreign policy (Ostpolitik) by awarding, since the late 1960s, many fellowships to scholars originating from this region. One can also notice a correlation between some communist countries' struggle to become more autonomous from the USSR, and the increased support of the Humboldt Foundation for scholars from these specific countries. Two relevant examples in this respect are the cases of Czechoslovakia around the time of the "Prague Spring” and Romania during the first years following Ceaușescu's rise to power. One can also notice the decrease in the number of Humboldt fellows from East European countries, once their regimes evolved towards a more authoritarian model and preferred to pursue more distant relations with the West.

The presence of scholars from the Eastern bloc in West Germany during the Cold War most probably played a significant role not only in their professional development, but also in the shaping of their political values. My findings indicate that, although not explicitly, the Foundation's officials were sensitive and open to this possibility. A Foundation's report from 2000 confirms this hypothesis:

"Worthy of special mention is the fact that many Humboldtians sponsored under a fellowship programme at universities and research institutions in Germany during the Cold War now hold leading positions in government, the legislatures and the judiciary and contribute substantially to the shaping of the democratization process in Central and Eastern Europe. The Foundation's sponsorship programmes are not designed primarily to produce leading politicians. But it has been proven that science, which is essentially international and open, constitutes the medium through which a disproportionately large number of the members of the new elite are recruited" $"$.

This article leaves plenty of open questions, including: the professional and political profile of the Humboldt fellows from Eastern Europe; the conditions

80 „New programme initiatives for the promotion of research in Central and Eastern Europe”, in Alexander-von-Humboldt Stiftung / Foundation, Jahresbericht / Annual Report 2000, 16. 
under which they were allowed to travel and carry out research in the West; their surveillance and control by the secret police in their countries of origin (or even their collaboration with the communist secret services); the data stored in the files of these secret services concerning these scholars; and, finally, the impact that the Alexander von Humboldt fellowships had on the countries of the Soviet bloc. All these questions will hopefully be addressed and answered by further research on this fascinating topic.

\section{Rezumat:}

Fundația Alexander von Humboldt a fost reînființată în Republica Federală Germania în 1953, cu scopul de a reafirma rolul de mare putere culturală a Germaniei și de a-i marca locul pe scena internațională. Fundația a acordat burse prestigioase cercetătorilor din străinătate, criteriile fiind excelența academică și lipsa oricărei cote. Inițial sporadică, relația Fundației cu țările din Europa de Est a început să se dezvolte către sfârșitul anilor 1960, în ciuda sistemelor politice diferite ale celor două blocuri. Acest lucru s-a întâmplat în contextul noii politici externe a RFG, orientată către Europa de Est (Ostpolitik), și s-a datorat, printre altele, și unei mai mari deschideri a țărilor socialiste către Occident. Relația a fost însă marcată de tensiuni, căci interesele politice au dominat obiectivele culturale sau academice. Articolul abordează tematica bursierilor Humboldt din Europa de Est în timpul Războiului Rece, concentrându-se, dintr-o perspectivă comparativă, pe aspectul cantitativ, precum și pe dinamica politică care a determinat prezența acestor bursieri est-europeni în Germania de Vest.

Cuvinte-cheie: Germania de Vest, blocul sovietic, Războiul Rece, relații academice, bursele Humboldt.

Irina Nastasă-Matei, University of Bucharest. Email: irina nastasa@yahoo.com 